Suchariewa, Switłana, i Jaruczyk, Olga. «Indywidualizacja stylu w ukraińskich przekładach wierszy ks. Jana Twardowskiego (na przykładzie zbioru poetyckiego “Trzeba iść dalej...”)». Лінгвостилістичні студіï, вип. 12, 2020, с. 203-11.

Sukharieva, Svitlana, and Yaruchyk, Olga. "Style Individualization in the Ukrainian Translations of Fr. Jan Twardowski's Poems (Case Study of the Book of Poems "We must go on ...")". Linguostylistic Studies, iss. 12,2020 , pp. 203-11.

УдК 821.162.1.09:81'255.4

https://doi.org/10.29038/2413-0923-2020-12-203-211

\title{
INDYWIDUALIZACJA STYLU \\ W UKRAIŃSKICH PRZEKŁADACH WIERSZY KS. JANA TWARDOWSKIEGO (NA PRZYKŁADZIE ZBIORU POETYCKIEGO “TRZEBA IŚĆ DALEJ...”)
}

\author{
Switłana Suchariewa \\ Wschodnioeuropejski Uniwersytet Narodowy im. Łesi Ukrainki, \\ Łuck, Ukraina \\ Olga Jaruczyk \\ Wschodnioeuropejski Uniwersytet Narodowy im. Łesi Ukrainki, \\ Łuck, Ukraina
}

W artykule ukazano stylistyczne osobliwości poezji ks. J. Twardowskiego oraz ich odpowiedniki w przekładach ukraińskich zamieszczonych $\mathrm{w}$ dwujęzycznym tomie poetyckim wydanym przez T. Czernysz i S. Jermolenkę. Zbadane są sposoby stosowania środków stylistycznych wskazujących na poziom przedstawienia w ukraińskich wariantach wierszy pełni autorskich obrazów. Zwrócono uwagę na metaforyzację bytu i przyrody, specyfikę syntaktyczną i interpunkcyjną dzieł Twardowskiego. Pojęcie "obraz" stało się głównym punktem odniesienia $\mathrm{w}$ analizie typowych i indywidualnych środków stylistycznych oraz rozbudowanych wyrażeń semantycznych.

Wyrazy kluczowe: transformacje przekładowe, styl autora, metoda porównawczej analizy thumaczenia, cechy stylistyczne, nieprzekładalność.

Сухарєва Світлана, Яручик Ольга. Індивідуалізація стилю в українських перекладах віршів о. Яна Твардовського (на прикладі поетичної збірки «Треба йти далі...»). У статті представлено стилістичні особливості поезії о. Я. Твардовського та їхні відповідники в українських перекладах на прикладі двомовного поетичного тому у перекладі Т. Черниш та С. Єрмоленка. Простежено способи використання перекладацьких конструкцій, які вказують на рівень засвоєння в українських варіантах віршів образного авторського наповнення. Звернено увагу на метафоризацію побуту та природи, синтаксичну та пунктуаційну специфіку творів Твардовського. Поняття «образ» стало основною точкою відліку під час аналізу індивідуальних і типологічних лексем і поширених семантичних висловлювань.

Ключові слова: перекладацькі трансформації, авторський стиль, метод порівняльного перекладацького аналізу, стилістичні особливості, неперекладність.

(C) Suchariewa S, Jaruczyk O., Східноєвропейський національний університет імені Лесі Українки, 2020.

Це стаття відкритого доступу на умовах СC BY-NC 4.0 


\section{STYLE INDIVIDUALIZATION IN THE UKRAINIAN TRANSLATIONS OF FR. JAN TWARDOWSKI'S POEMS \\ (CASE STUDY OF THE BOOK OF POEMS “WE MUST GO ON ...”) \\ Svitlana Sukharieva}

Lesya Ukrainka Eastern European National University, Lutsk, Ukraine

\section{Olga Yaruchyk}

Lesya Ukrainka Eastern European National University, Lutsk, Ukraine

The article considers the stylistic features of Fr. J. Twardowski's poetic works and their equivalents in the Ukrainian translations. The case study of the issue is the bilingual poetic volume of We must go on or a ladybug walk translated by T. Chernysh and S. Yermolenko. The issue of the value identity, present in the original and translations, is argued by determining the typological and individual features of translation transformations. The author analyzes the ways of using translation constructions, indicating the level of assimilating figurative language of the original poems in Ukrainian versions, with a focus on the metaphorization of life and nature, syntactic and punctuation specifics of the poems by Fr. J. Twardowsk. The study argues that a form of vers libre provides translators with new opportunities for transmitting the author's symbols to the Ukrainian reader. The preservation of the inner rhythm of the poems, their melody, thoughtful structure, which is associated with the phenomenon of the concept of "image" have been emphasized.

The concept of "image" has become the starting point in the analysis of individual and typological lexical items and common semantic expressions. The compliance analysis (translation equivalence) allows better understanding of the original structures and facilitates the general vision of the reproduction correctness of the original communicative intentions in the translation. In addition, the work combines linguistic and stylistic approach with a general interpretive and cultural method, which allows identifying the individual style of the author and the degree of translator's adaptation of them to the Ukrainian realities.

The key findings of the study manifest that the author's most favored stylistic means and devices are: anaphora, obvious and hidden antonymy, metaphorical expressions, conveying the Polish realities in which he lived and worked, religious symbols, emotionality of the colloquial vocabulary, and dialogism of the style. The conclusion is that Twardowski's poems in the book of poems "We must go on..." are translated into Ukrainian at a high professional level, there are many individual findings, although it is not the only possible way to reveal the author's style. It is advisable to analyze stylistic features of the whole complex of Twardowski poetry translations into Ukrainian in future researches.

Key words: translation transformations, writing style, method of comparative translation analysis, stylistic features, untranslatability.

Wstęp. Poezja Jana Twardowskiego (1915-2006) - artysty, księdza i myśliciela - w ostatnich dekadach zdobyła tak ogromną popularnośc, że chętnie jest tłumaczona $w$ wielu językach świata, $w$ tym też $w$ języku ukraińskim. Jej fenomen połączenia sakraliów i rzeczy ziemskich w autorskim "języku wiary" tworzy niepowtarzalną stylistykę, której należy poświęcić więcej uwagi. Dzieła poetyckie ks. J. Twardowskiego na język ukraiński tłumaczyli tacy współcześni naukowcy i literaci, jak T. Czernysz i S. Jermolenko (Twardowski), Ł. Demska (Твардовський, Вибрані поезіï), D. Matiasz (Твардовський, Гербарій; Твардовський, Ще одна молитва), M. Stricha (Улюблені), jednak badania obecnych przekładów na razie są nikłe i pozostają na marginesie 
translatoryki. Ze wgledu na to $\mathrm{w}$ tej publikacji podejmujemy próbę analizy przetłumaczonych na język ukraiński wierszy ks. J. Twardowskiego skupiając uwagę na aspektach stylistycznych.

Celem badania jest analiza stosowanych środków stylistycznych w wierszach ks. J. Twardowskiego i ich porównanie ze środkami stylistycznymi w ich przekładach ukraińskich.

Materiał i metody badawcze. Obiektem obecnych studiów stało się dwujęzyczne wydanie wierszy ks. J. Twardowskiego "Trzeba iść dalej czyli spacer biedronki" - "Треба йти далі або прогулянка сонечка" w tłumaczeniu T. Czernysz i S. Jermolenki (Twardowski). Ma to się stać krokiem ku syntezie translatorycznej wszystkich ukraińskich przekladów wierszy ks. Twardowskiego. Posłuży również pomocą do następnych tłumaczeń $\mathrm{w}$ wybranym zakresie literackim $\mathrm{z}$ uwzględnieniem zalet poprzednio powstałych przekładów. Dla osiągnięcia postawionego celu głównie stosowaliśmy metodę analizy porównawczej oryginału i przekładu poprzez porównanie uzytych $\mathrm{w}$ nich ukraińskich i polskich środków stylistycznych. Analiza zgodności pozwala na dogłębne zrozumienie struktury oryginału i wspólnej wizji prawidłowej reprodukcji intencji komunikacyjnych oryginału $\mathrm{w}$ tłumaczeniu. Ponadto, podejście lingwostylistyczne połączyliśmy z ogólną metodą interpretacyjnokulturologiczną, dzięki czemu jest możliwe rozeznanie indywidualnego stylu autora istopnia jego adaptacji do realiów ukraińskojęzycznych (Чередниченко).

Wyniki badania i dyskusja. W oparciu o twierdzenie D. Rudyka zgadzamy się z myślą, iż: "Każde tłumaczenie koniecznie musi zachować trzy główne części oryginału: fabułę, styl i rytm. W obecnej sytuacji możliwości przekładowych ogólnie możemy jeszcze prowadzić dyskusje, czy możliwa jest pełna niwelacja tłumacza, jego "ja". Za kryterium dokładności tłumaczenia można niewątpliwie uznać pomysł autora oryginału" (Рудик 119). Ogólnie rzecz biorąc, powstaje pytanie, $\mathrm{w}$ jakim stopniu następuje przekładowe odczytanie kodów tekstów literackich, treść których została zbadana $\mathrm{w}$ pracach R. Zoriwczak (Зорівчак 30-36).

Przede wszystkim rzuca się $\mathrm{w}$ oczy kształt wierszy Twardowskiego, rzadko rymowanych zewnętrznie, posiadających jednak budowę rytmiczną. Wiemy, że rymowanie było właściwe tylko na wczesnym etapie twórczości poety, kształtowanej w oparciu o lirykę grupy "Skamander", rozmiłowanej w wierszu wolnym przynależącym do systemu nienumerycznego.

$\mathrm{Z}$ tego okresu pisarzowi również pozostało zanurzenie w poetyzacji bytu powszedniego, nowatorstwo obrazowe, ukryty lub widoczny dialog $\mathrm{z}$ czytelnikiem. Cechy te zauważamy $w$ przedwojennej i wojennej poezji Twardowskiego, wykształconego polonisty, losy którego po Powstaniu Warszawskim potoczyły się w kierunku misji duszpasterskiej.

Autorzy ukraińskich przekładów zbioru "Trzeba iść dalej czyli spacer biedronki" T. Czernysz i S. Jermolenko dokładnie uwzględnili ten sposób 
stylizacji, w żadnym miejscu nie odstępując od wizji autorskiej. Zostało to uwidocznione w identycznych formach graficznych:

\section{Pisanie}

Jezu który nie brałeś pióra do ręki nie pochylałeś się nad kartka papieru nie pisałeś ewangelii

dlaczego nie pisze się tak jak się mówi nie pisze się tak jak się kocha nie pisze się tak jak się cierpi nie pisze się tak jak się milczy

pisze się trochę tak jak się nie jest

(Twardowski 230)

\section{Писання}

Ісусе що не брав у руки пера не схилявсь над аркушем паперу не писав Євангелій

чом ми не пишемо так як говоримо не пишемо так як любимо не пишемо так як страждаємо не пишемо як мовчимо

пишемо трохи не так як $\epsilon$

(Twardowski 231)

Tak więc całokształt odbioru świata uległ znacznej indywidualizacji, co niejednokrotnie przypomina czytelnikom fragmenty znakomitego kazania ujętego $\mathrm{w}$ formę literacką. Często stosowanym przez Twardowskiego chwytem artystycznym jest anafora, która w szczególny sposób służy jako znak rozpoznawczy stylu autorskiego. W wyżej zacytowanym wierszu "Pisanie" tę funkcję pełni wyraz 'nie pisze się' tworzący parę antonimiczną z podsumującym wyrażeniem 'pisze się trochę taj jak nie jest'. Podobnie w ramach konceptu, a niekiedy metakonceptu są zaprezentowane też inne struktury anaforyczne $\mathrm{w}$ dziełach oryginalnych: "przed czym uciekasz <...> - przed czym drżysz <...>-przed czym się bronisz obiema szczękami" ("Przeciw sobie") (Twardowski 144). Tej regularności stylistycznej nie zauważamy w ukraińskich przekładach, niekiedy zindywidualizowanych i mało rozpoznawanych pod wzgledem stylistycznym. Tak, w ukraińskiej wersji wiersza "Przeciw sobie" ("Проти себе") czytamy:

За те молись чого не хочеш ти

і що тебе як білку дощ лякає

те від чого як гуска утікаєш

тремтиш як взимку у благенькому пальті

боронишся вночі уранці вдень

пора вже проти себе помолитись

за те найбільше що саме прийде (Twardowski 145).

Jednak tłumacze zachowują najważniejszą parę zaimkową budującą całość fabuły poetyckiej: 'czego - o to' ('щo - за me'), w ten sposób przedstawiając stylistyczny wymiar wiersza. Na podstawie tych transformacji przekładowych dochodzimy do wniosku o konieczności indywidualnego podejścia autorów tłumaczeń do regularnych cech oryginałów. Zjawisko to występuje z powodu specyficznych cech melodii i składni języka ukraińskiego, który potrafi na swój sposób oddać te same treści semantyczne nie tracąc na ich bogactwie i różnorodności symbolicznej. Stąd powstają konstrukcje różniące się na 
poziomie składniowo-morfologicznym, lecz doskonale odzwierciedlające najdelikatniejsze podteksty znaczeń semantycznych:

- "Przyszedłem Ci podziękować" - "Спасибi Тобі мій Боже” (Twardowski 154-155); "Ten którego kochajq zostanie zbawiony" - "Тим кого люблять суджене спасіння" (Twardowski 264-265);

- "Broń bym zdobył dla Ciebie, o głodzie wędrował" - "Я з Тобою пішов би на бій і на муки" (Twardowski 30-31);

- "Pożegnać wikariatkę na niewielkim piętrze" - "Піднятись у кімнатки свої на прощання" (Twardowski 30-31);

- "Jarzębiny przy drogach coraz rzadsze" - "Горобино узбічна, яку вже й не стріти" (Twardowski 304-305).

Czasem tłumacze są zmuszeni do transformacji metonimicznych ("nareszcie mogę widzieć swa twarz nieszczęśliwq" - "і очі я свої побачу, певні суму" (Twardowski 34-35); "gdy mróz mi kości lizał przez palto zimowe" - "хоч i лизав мене мороз через убрання" (Twardowski 36-37)) lub synonimicznych, bardziej przemawiających ("jak piersi na wierzchu" - "як ноги 3-під спідниці міні" (Twardowski 370-371); "Pan Guzik pojął za żonę pannę Petelkę" - "Пан Бублик взяв шлюб із панною Діркою" (Twardowski 354-355)), aby lepiej oddać treść wyrażeń w kategoriach ukraińskich. Uzupełnia te transfomacje aspekt morfologiczny, jak w wierszu "Na miejskim placu" zmiana form rzeczownikowych na przysłówkowe powołanych do ukazania stanu wewnętrznego: "i nagle ta czystość i jasność, i ciepło" - "і зненацька так чисто, світло і тепло" (Twardowski 36-37).

Wariatywność frazeologiczna zależy od możliwości przekładowego kalkowania, które nie zawsze da się zastosować nawet w tak bliskich językach jak ukraiński i polski. Tak, w środowisku polskim siłę utożsamia się z koniem, co niejednokrotnie zauważa $\mathrm{w}$ swoich poezjach Twardowski, natomiast $\mathrm{w}$ frazeologii ukraińskiej tę rolę przypisuje się bykowi lub wołowi: "gdyby wszyscy byli silni jak konie" - “якби усі були здорові як бик" (Twardowski 74-75).

W niektórych przypadkach autorzy przekładów odstępują od tej reguły, dla większej wyrazistości stosując kalki frazeologiczne, jednak słusznie komentując ich znaczenie na marginesach książki, ponieważ bez tych tłumaczeń treść wyrażeń byłaby niezrozumiała. Tak, wymagają skomentowania następujące wyrażenia:

- "nie chce nie dba żartuje" - "не хоче не дбає жартує” (ukr. odpowiednik “любить - не любить") (Twardowski 160-161),

- "Ala ma cnote ale nie ma kota" - "Є цнота у Майї але кота немає" (parafrazowany wierszyk z polskiego elementarza) (Twardowski 188-189),

- "z gromnica na wszelki przypadek" - "із громничою свічкою про всяк випадок" (chodzi o katolicką tradycję poświęcenia świecy podczas uroczystości Nawiedzenia Najświętszej Marii Panny (Twardowski 164-165) itp.

Podobne środki przekładowe jako kalkowanie stylistyczne są powołane do zachowania klimatu, w którym się kształtował poziom kulturowoobyczajowy poety. Ważną rolę odgrywa także czynnik interpretacyjno- 
kulturologiczny dotyczący kwestii tożsamości narodowej, równie ważnej, jak uniwersalna pozycja humanistyczna. Zachęca to nie obeznanych z inną kulturą czytelników sięgnąć po jej wartości, co wyraża się przede wszystkim w zakresie tematycznym. Twardowski potrafił tradycyjną paletę tematów rozpatrzyć w nowej perspektywie, zamieniając rzeczy bytowe w nowe odkrycia estetyczne. To dzięki metaforze ożywiają się fragmenty codzienności i zaczerpnięte z nich obrazy:

- "ze świętym Antonim od zgubionego klucza" ("із святим Антонієм що ключі знаходить загублені") (Twardowski 164-165),

- "warkoczyk tak wierny jak anioł prywatny" ("кіску вірну як приватний янгол") (Twardowski 68-69),

- "kapelusz z lat szkolnych co młodość иdaje" ("шапочка шкільна що юність удає") (Twardowski 198-199),

- "bocian $w$ gnieździe otwartym obraca się $w$ słońcu by stale swym cieniem pisklęta zasłaniać" ("лелека у гнізді до сонця так стає щоб усе в тіні були лелеченята") (Twardowski 266-267),

- "ile spodni już pękło co miały być zawsze" ("скільки штанів тріснуло навіки пошитих") (Twardowski 304-305) itp.

Ten styl metaforyzacji rzeczywistości tworzy "język wiary”, dzięki któremu poezja Twardowskiego wyróżnia się na ogólnym literackim tle współczesnej epoki. Najbardziej pełne przejście od sfery bytowej na wszystkich jej płaszczyznach do rzeczy duchowych odnajdujemy w wierszu "Niewidoma dziewczynka":

Matko mówiła niewidoma dziewczynka tuląc się do Jej obrazu

Korona Twoja zimna - ślizgam się po niej jak po gładkiej

sq̨ kolory tak ciężkie że odstajq̨ od przedmiotu

[szybie

to co złote chodzi swoimi drogami i żyje osobno

Słucham szelestu Twoich włosów

idę chropowatym brzegiem Twojej sukni

odkrywam gorace źródła rąk

pomarszczona pończoszkę skóry

szorstkie szczeliny twarzy

żwir zmarszczek

tkliwość obnażenia

ciepłą ciemność

sprawdzam szramę jak bliznę po miłości

zatrzymuję tu oddech $w$ palcach

uczę się bólu na pamięć

zdrapuję to co przywarło ze świata jak śmierć niegrzeczna

wydobywam puszystość rzęs odwracam łzę

zbieram nosem zapach nieba 
odgaduję wreszcie małego Jezusa z potłuczonym

[spuchniętym kolanem na Twym ręku... (Twardowski 62)

$\mathrm{Na}$ pierwszy rzut oka wiele obrazów mogą wydać się $\mathrm{w}$ tym wierszu nieprzekładalne i na tyle indywidualne, że trudno wyobrazić, aby ktoś $\mathrm{z}$ tłumaczy podjął się zadania ująć całokształt zawartych w nich uczuć. Jednak autorzy wersji ukraińskiej doskonale poradzili sobie z oryginalnymi obrazami udostępniając czytelnikom pełnię zawiłości metaforycznych. Utwór został zatytułowany w nowej wersji językowej jako “Невидюща дівчинка”, gdyż autorzy tłumaczenia woleli uniknąć wyrazu 'cлina', który czasem ma konotacje negatywne. Powstaje szereg symboli przemawiających za niepowtarzalnością ludzkiego bytu, który potrafi wydobyć z kamienia głos, kolor, emocje: 'корона гладенька', 'важкі кольори', 'шелестіння волосся', 'шорсткий поділ сукні', 'гарячі джерела рук', 'збрижена панчішка шкіри', 'шерехаті щілини обличчя', 'щебінь зморшок', 'вразливість оголення', 'тепла темінь', 'рубець як шрам від любові', 'запах неба' (Twardowski 63).

Antynomia jako jeden $\mathrm{z}$ głównych środków stylistycznych została zachowana w postaci wersetów podsumujących, co też znacznie indywidualizuje styl poetycki:

nie umiesz oddać siebie

jakże masz dostać wszystko

("Jeszcze" (Twardowski 132))

można nawet zabłądzić lecz po drugiej

stronie

nasze drogi pocięte schodzq się $z$ powrotem

("Bliscy i oddaleni" (Twardowski 84))

Trzeba mieć ciało by odnaleźć duszę

("Tylko" (Twardowski 194))

не вмієш віддати себе

як же думаєш все отримати

("Iще" (Twardowski 133))

$i$ заблукати навіть можна на потойбіч

шляхи що перетнулись зійдуться нам знов

(“Близькі й далекі" (Twardowski 85))

Дає нам тіло душу віднайти

(“Лише" (Twardowski 195))

Jeśli chodzi o rozległość tematyczną, M. Olszewska określa ją w następujący sposób: "Znakiem Boga jest w poezji ks. Twardowskiego jego dzieło: przyroda i drugi człowiek. Kluczową wartością jest miłość - Boga do człowieka oraz człowieka do Boga i bliźnich. Paradoksalnie, równie istotna jest radosna zgoda na samotność i cierpienie, wpisane $\mathrm{w}$ porządek świata i pozwalające człowiekowi stać się "przezroczystym", otwartym na działania Boga. Przewodniczką w wierze jest Matka Boża - w poezji ks. Twardowskiego silny jest nurt mariologiczny" (Olszewska). Te wszystkie unowocześnione wątki homiletyczne w ukraińskich przekładach wierszy Twardowskiego pozostają niezmienne. Mamy do czynienia z kazaniami nowego gatunku - oddolnymi, tzn. wywodzącymi się $\mathrm{z}$ realiów bytu codziennego i podążającymi $\mathrm{w}$ kierunku metaforyzacji i sakralizacji obrazów.

Sztywna forma wierszy niejednokrotnie powoduje stosowanie przez tłumaczy zindywidualizowanych środków lingwostylistycznych w języku 
ukraińskim, gdzie rytmiczna budowa wiersza wolnego wymagałaby innych akcentów i liczby sylab. Zatem w pewnym stopniu posłabia to wyrazistość przesłania autorskiego. To, co w oryginale uważano za indywiduazizację form, $\mathrm{w}$ przekładach poniekąd staje się typiczną cechą stylistyczną, ponadto nie zawsze odpowiednią. Jednak te przejawy sztywności są słabo zauważalne i ogólnie nie psują wrażenia odbiorców przekładów o oryginalnym stylu autorskim.

Równie ważną funkcję stylistyczną w przekładach pełni interpunkcja. Dokładnie ten aspekt przekładowy został opracowany w publikacji H. Majfeta: "Problem <...>, jak się wydaje, ogólnie jeszcze nie postawiono... Pierwszą przeszkodą dosformułowania tego problemu w pełni jest charakterystyczna dla języków różnica w systemach interpunkcyjnych i brak ich naukowego opracowania" (Майфет 254-255).

W przypadku z ukraińskimi przekładami wierszy Twardowskiego w kolejny raz chodzi o naśladowcze ujęcie obrazów, w tym brak znaków interpunkcyjnych dodaje wyrazom rozciągłości. Kilka wyjątkowo użytych przecinków pełni szczególną funkcję stylistyczną akcentując uwagę czytelnika na pauzie przede wszystkim myśleniowej, a nie tylko zewnętrznej. Milczenie poety $w$ ten sposób też przemawia wypełniając przestrzeń treścią symboliczną.

Wnioski i perspektywy badań. Na podstawie przeprowadzonej analizy porównawczej dzieł oryginalnych ks. J. Twardowskiego i ich przekładów w języku ukraińskim, zawartych $\mathrm{w}$ tomie poetyckim "Trzeba iść dalej czyli spacer bedronki", doszlismy do wniosku, że oba warianty poetyckie są dogłębnie metaforyczne, gdyż autorzy przekładów słusznie uwzględnili morfologiczne, składniowe i semantyczne osobliwości języka ukraińskiego, dzięki czemu wiersze Twardowskiego mogą w pełni swych znaczeń dotrzeć do czytelnika. Czy udał się ten eksperyment translatoryczny? Z pewnością tak, jeśli chodzi o oddanie stylu autorskiego zawartego w oryginałach.

Wśród wielu różnych sposobów stylizacji wewnątrztekstowej należy wyróżnić struktury metaforyczne, metonimiczne, formalne (kształt wiersza wolnego, budowa rytmiczna, brak interpunkcji), podsumowania antynonimiczne, kalkowanie, transformacje morfologiczne i składniowe, anafory. Mimo tej różnorodności środków indywidualizacji tekstów ptrzetłumaczonych odkryliśmy wysoki stopień zgodności treści i form oryginałów i ich przekładów na język ukraiński.

Oczywiście, nie jest to jedyne rozwiązanie przekładowe, które należy stosować $\mathrm{w}$ trakcie tłumaczenia wierszy Twardowskiego. Istnieje też wielu innych transformacji przekładowych, które by się przydały do tłumaczenia poezji Twardowskiego i czym się właśnie zajmują niektórzy tłumacze ukraińscy, którymby należało poświęcić odrębne badanie naukowe.

\section{Spis wykorzystanej literatury}

Зорівчак, Роксолана. «Реалія як перекладознавча категорія: (На матеріалі англомовних перекладів української прози)». Іноземна філологія. Львів, 1983, вип. 71, с. 30-6.

Майфет, Григорій. «Рецензія на кн.: Бокаччо Дж. Декамерон». Червоний шлях, № 2, 1930, c. 252-8. 
Рудик, Дмитро. «Гайнріх Гайне в новому перекладі: [рецензія]». Життя і революція, кн. 10,1930 , с. 105-124.

Твардовський, Ян. «Вибрані поезії». Переклад з пол. Л. Демська. Всесвіт, № 3-4, 2017, с.32-41.

Твардовський, Ян. Гербарій. Переклад з пол. Д. Матіяш. Київ: Грані-Т, 2008.

Твардовський, Ян. Ще одна молитва. Переклад з пол. Д. Матіяш. Київ: Грані-Т, 2009.

Улюблені переклади: поезії. Переклад М. Стріха. Київ: Український письменник, 2015.

Чередниченко, Олександр. Переклад - Культура - Ідентичність. Київ, 2017.

Olszewska, Małgorzata. Jan Twardowski. Antologia polskiej poezji od Średniowiecza do wieku XXI. URL : https://culture.pl/pl/tworca/jan-twardowski.

Twardowski, Jan. Trzeba iść dalej czyli spacer biedronki. Треба ти далі або прогулянка сонечка. Переклад Т. Черниш і С. Єрмоленко. Київ: Кайрос, 2000.

\section{References}

Zorivchak, Roksolana. "Realiia yak perekladoznavcha katehoriia: (Na materiali anhlomovnykh perekladiv ukrainskoi prozy)”. Inozemna filolohiia. Lviv, 1983, iss. 71, pp. 30-6.

Maifet, Hryhorii. "Retsenziia na kn.: Bokachcho Dzh. Dekameron". Chervonyi shliakh, no. 2, 1930, pp. 252-8.

Rudyk, Dmytro. "Hainrikh Haine v novomu perekladi: [retsenziia]". Zhyttia i revoliutsiia, kn. 10, 1930, pp. 105-124.

Twardowski, Jan. “Vybrani poezii”. Pereklad z pol. L. Demska. Vsesvit, no. 3-4, 2017, pp. 32-41.

Twardowski, Jan. Herbarii. Pereklad z pol. D. Matiiash. Kyiv: Hrani-T, 2008.

Twardowski, Jan. Shche odna molytva. Pereklad z pol. D. Matiiash. Kyiv: Hrani-T, 2009.

Uliubleni pereklady: poezii. Pereklad M. Strikha. Kyiv: Ukrainskyi pysmennyk, 2015.

Cherednychenko, Oleksandr. Pereklad - Kultura - Identychnist. Kyiv, 2017.

Olszewska, Małgorzata. Jan Twardowski. Antologia polskiej poezji od Średniowiecza do wieku $X X I$. culture.pl/pl/tworca/jan-twardowski.

Twardowski, Jan. Trzeba iść dalej czyli spacer biedronki. Treba ty dali abo prohulianka sonechka. Pereklad T. Chernysh i S. Yermolenko. Kyiv: Kairos, 2000. 